\title{
Removal of Lithium Citrate from H3A for Determination of Plant Available $P$
}

\author{
Richard L. Haney¹, Elizabeth B. Haney², Douglas R. Smith¹, Michael J. White ${ }^{1}$ \\ ${ }^{1}$ USDA-ARS, Grassland, Soil and Water Research Laboratory, Temple, USA \\ ${ }^{2}$ Texas A \& M University, Texas AgriLife Research and Extension Center, Temple, USA \\ Email: rick.haney@ars.usda.gov
}

How to cite this paper: Haney, R.L., Haney, E.B., Smith, D.R. and White, M.J. (2017) Removal of Lithium Citrate from H3A for Determination of Plant Available P. Open Journal of Soil Science, 7, 301-314. https://doi.org/10.4236/ojss.2017.711022

Received: September 15, 2017 Accepted: November 10, 2017 Published: November 13, 2017

Copyright (c) 2017 by authors and Scientific Research Publishing Inc. This work is licensed under the Creative Commons Attribution International License (CC BY 4.0).

http://creativecommons.org/licenses/by/4.0/

(c) (i) Open Access

\begin{abstract}
The soil extractant, H3A, has undergone several iterations to extract calcium $(\mathrm{Ca})$, iron $(\mathrm{Fe})$, aluminum $(\mathrm{Al})$, potassium $(\mathrm{K})$, phosphorus $(\mathrm{P})$, ammonium $\left(\mathrm{NH}_{4}-\mathrm{N}\right)$ and nitrate $\left(\mathrm{NO}_{3}-\mathrm{N}\right)$ under ambient soil conditions. Few soil extractants currently used by commercial and university soil testing laboratories can perform multi-nutrient extraction without over- or under-estimating at least one nutrient. Soil $\mathrm{pH}$ and plant root exudates have a strong influence on nutrient availability and $\mathrm{H} 3 \mathrm{~A}$ was developed to mimic soil conditions. Lithium citrate was previously used in the H3A formulation, but resulted in a cloudy supernatant in some samples, complicating laboratory analyses. In this study, we removed lithium citrate and compared the nutrients extracted from the modified (H3A-4) to the established (H3A-3) solutions. We found that the new extractant, H3A-4, produced a clear supernatant even in soils with low $\mathrm{pH}$ and high iron and aluminum concentrations. H3A-4 accurately predicts plant available nutrients and is a viable choice for commercial and laboratory settings due to its ease of use.
\end{abstract}

\section{Keywords}

Phosphate, Soil Extraction, Lithium Citrate

\section{Introduction}

Few currently available soil extractants are capable of multi-nutrient extraction without sacrificing accuracy for one compound or another [1]. Plant-available soil $\mathrm{P}$ has been difficult to accurately assess across the naturally occurring $\mathrm{pH}$ range of soils (calcareous to acid) with a single extractant because soil $\mathrm{pH}$ and $\mathrm{P}$ solubility are highly interrelated [2] [3] and soil $\mathrm{pH}$ has a strong influence on soil-solution chemistry [4]. Thus multiple extractants have been developed to 
determine "plant available" $\mathrm{P}$ depending upon the $\mathrm{pH}$ of the soil being analyzed. Mehlich 3 [5] was developed for use in neutral to acid soils, while the Olsen extractant was developed primarily to extract $\mathrm{P}$ from calcareous soils [6]. Their development demonstrates early awareness of the difficulty of accurately extracting plant available $\mathrm{P}$ across such a wide range in natural conditions. Despite its development for neutral to acid soils, Mehlich 3 is commonly used without regard to soil $\mathrm{pH}$. In addition, Mehlich 3 cannot be used for $\mathrm{NH}_{4}-\mathrm{N}$ and $\mathrm{NO}_{2}$ $\mathrm{N} / \mathrm{NO}_{3}-\mathrm{N}$ analysis.

The need for rapid analysis in commercial and university soil-testing labs contributed to use of soil extractants outside of the soil conditions for which they were developed. Using strong acid extractants such as Mehlich $3(\mathrm{pH} \sim 3)$ or alkaline extractants such as Olsen ( $\mathrm{pH} \sim 8.5$ ) without regard to soil $\mathrm{pH}$ can result in over-estimation of plant-available P. As Menon et al. (1988) stated "a major disadvantage in using extracting solutions; however, is that they may mobilize not only the phosphate available for plant use but also some otherwise stable and non-mobile soil components." For instance, Mehlich 3 releases significantly more P than other extractants [7] [8] [9] by dissolving relatively insoluble fractions of Ca-, Al- and Fe-associated P [10]. Menon et al. (1988) suggest that deionized water and the anion exchange resin method (FeAlO exchange) do not experience the limitations common with other extracting solutions. While FeAlO exchange is an accurate method for the measurement of plant available P [3] [7], it is slow and cumbersome. In addition, there are well known analytical issues with water extraction, such as cloudy extract resulting in instrument interference. Therefore, few, if any, commercial labs offer FeAlO and water extractions for large scale routine soil analysis.

H3A-1 [11] and its subsequent modifications, H3A-2 and H3A-3 [12], were developed to mimic the plant root environment by utilizing organic acid plant exudates [13] [14] to extract nutrients at ambient soil $\mathrm{pH}$, with the additional benefit of simultaneous N, P and K extraction. Many organic acids exuded by plant roots have been identified. Three exuded by plants species such as corn, wheat, and sorghum are malic, citric, and oxalic acid [15]. These organic acids are used in $\mathrm{H} 3 \mathrm{~A}$ and have a low buffering capacity, which allows the soil $\mathrm{pH}$ to dominate the $\mathrm{pH}$ of the extractant solution in soil [11]. The effort to mimic the soil-root environment is important since plants utilize root exudates to overcome P, Fe, Zn, and Mn deficiencies [13] [16] [17]. Ion toxicity and pathogen attack can also stimulate an exudate response from plants [18] [19] [20]. The mechanism for increased $\mathrm{P}$ availability from plant-root exudates is mediated by a decrease in soil $\mathrm{pH}$ at the plant root-soil interface, which induces ligand exchange, dissolution, and binding to exchange sites by organic acids exudates that release ligand-bound $\mathrm{P}$ to the soil solution [21]. As the $\mathrm{pH}$ of the soil increases, the acids struggle to extract $\mathrm{P}$ as the effects of soil calcium take effect, much like in the Texas Houston Black (fine, smectitic, thermic UdicHaplusterts) soils ( $\mathrm{pH}$ 8.3) of the Blackland Prairie. In the Blackland Prairie, agriculture producers 
generally see a crop response to $\mathrm{P}$ fertilizer additions. H3A has been able to accurately reflect limited availability of $\mathrm{P}$ in these soils as the extracting power of $\mathrm{H} 3 \mathrm{~A}$ decreases in proportion to increases in soil $\mathrm{pH}$ [22]. $\mathrm{H} 3 \mathrm{~A}$ begins to extract less soil $\mathrm{P}$ around $\mathrm{pH} 7.7$ where free $\mathrm{CaO}_{3}$ is abundant [12].

The original $\mathrm{H} 3 \mathrm{~A}$ formulation and processing methods were altered to address the occurrence (roughly 5\%) of soil extracts that did not have a visually clear supernatant with H3A-1 (Haney et al., 2010). Samples with a cloudy supernatant also had elevated $\mathrm{Fe}, \mathrm{Al}$, and $\mathrm{P}$ concentrations when analyzed using other well-known soil extractants. To resolve this issue, H3A-1 was modified and tested on 60 soils from the NAPT (North American Proficiency Testing) program with varying $\mathrm{pH}$, organic $\mathrm{C}$, and clay content. The modifications deemed H3A-2 included eliminating the use of EDTA and DTPA and reducing the shaking time from $30 \mathrm{~min}$ to $5 \mathrm{~min}$. $\mathrm{H} 3 \mathrm{~A}-2$ reduced the extractable $\mathrm{Fe}$ and $\mathrm{Al}$ concentrations and improved the relationships for extractable $\mathrm{NO}_{3}, \mathrm{NH}_{4}, \mathrm{PO}_{4}$, total $\mathrm{P}, \mathrm{K}, \mathrm{Ca}$ and $\mathrm{Zn}$ with the Olsen, $\mathrm{KCl}$, water, Mehlich 3, Bray 1, $\mathrm{NH}_{4} \mathrm{OAc}$ extractants [12].

H3A-2 contained lithium citrate (Li-citrate). The concentration of Li citrate was reduced resulting in the formulation of H3A-3. Becauseanalysis with FeAlO strips are considered to best represent plant available $P$ in soils [3] [7], we compared the relationships between $\mathrm{H} 3 \mathrm{~A}-2$ and $\mathrm{H} 3 \mathrm{~A}-3$ extractable $\mathrm{P}$ with FeAlO P.H3A-3 extractable $\mathrm{P}$ was strongly correlated with $\mathrm{P}$ from FeAlO strip extraction results $\left(\mathrm{r}^{2}>0.96, \mathrm{P}<0.001\right)[22]$.

As we continually endeavor to mimic nature in the lab, it is logical to remove Li citrate since it is not a naturally occurring organic compound. In the past, we made the mistake of synthetically forcing a natural process to conform to a lab method rather than allowing the natural process to drive lab methodology. Lithium citrate buffered organic acids in $\mathrm{H} 3 \mathrm{~A}$ to stabilize extractant $\mathrm{pH}$ and extractable $\mathrm{P}$ across a range of soils; however, this process does not occur in the field. Plants control their response to $\mathrm{P}$ deficiency by changing the organic acid strength or type of acid they exude into the soil [23]. The objective of this study was to compare extractable $\mathrm{P}$ from H3A-3 to extractable P from H3A-3 without Li-citrate (H3A-4). We believe that the removal of Li citrateis a necessary change in inching us ever closer to extracting solutions that mimicplant root and soil interactions.

\section{Methods}

Extractable $\mathrm{P}$ from a total of106 soils were analyzed with H3A-3 and H3A-3 without Li citrate (H3A-4). Thirty of the soils analyzed are from the North American Proficiency Testing (NAPT) program (http://www.naptprogram.org), and the other 76 are from surface soils (approximately $10 \mathrm{~cm}$ ) gathered in 2015 from throughout the contiguous United States (18 states). The soils analyzed have a wide range of soil $\mathrm{pH}$, clay content, tillage regimes, management and climatic conditions. 
The H3A extractant is slightly modified since the published formula included in Haney et al. (2016) and is termed H3A-4. The modified formula for H3A-4 is as follows.

\section{Liters Deionized Water}

1.1 grams Malic acid

0.7 grams Citric acid and

0.45 grams Oxalic acid.

The $\mathrm{pH}$ of the resulting extractant is 3.75 , and is weakly buffered.

The 106 soils were extracted with H3A-3 and H3A-4 by shaking 4-g samples on a Eberbach shaker with 40 -mlextractant for 10 minutes at 120 back and forth movements per minute. All samples were centrifuged for 5 minutes at $3500 \mathrm{rpm}$ at room temperature and filtered through What man $2 \mathrm{~V}$ filter paper prior to analysis for calcium $(\mathrm{Ca})$, iron $(\mathrm{Fe})$, aluminum $(\mathrm{Al})$, potassium $(\mathrm{K})$ and phosphorus (P) on an axial flow Agilent MP-4200 as well as a Seal Analytical rapid flow analyzer(RFA) for phosphate $\left(\mathrm{PO}_{4}-\mathrm{P}\right)$, ammonium $\left(\mathrm{NH}_{4}-\mathrm{N}\right)$ and nitrate $\left(\mathrm{NO}_{3}-\mathrm{N}\right)$. Data analysis was completed using SigmaPlot ver. 13 (Systat, Inc.) for regression analysis to determine the relationships between H3A-3 and H3A-4 extractable nutrients.

\section{Results and Discussion}

Soil $\mathrm{pH}$ values range from 4.2 to 8.5 . Averaged across all 106 samples from ICP analysis, H3A-3 extractable $\mathrm{P}$ ranges from $1.0 \mathrm{mg} \mathrm{P} \mathrm{kg}^{-1}$ soil to $215 \mathrm{mg} \mathrm{P} \mathrm{kg}^{-1}$ soil with a mean of $36.3 \mathrm{mg} \mathrm{P} \mathrm{kg}^{-1}$ soil, while $\mathrm{H} 3 \mathrm{~A}-4$ extractable $\mathrm{P}$ ranges from $1.0 \mathrm{mg} \mathrm{P} \mathrm{kg}{ }^{-1}$ soil to $227 \mathrm{mg} \mathrm{P} \mathrm{kg}^{-1}$ soil with a mean of $34.6 \mathrm{mg} \mathrm{P} \mathrm{kg}{ }^{-1}$ soil. H3A-4 extracted $95.4 \%$ of that extracted with H3A-3 from 106 samples (3672 $\mathrm{mg} \mathrm{P} \mathrm{kg}{ }^{-1}$ soil compared to $3849 \mathrm{mg} \mathrm{P} \mathrm{kg}^{-1}$ soil). H3A-4 extractable $\mathrm{P}$ was highly correlated with H3A-3 extractable $\mathrm{P}\left(\mathrm{r}^{2}=0.98, \mathrm{p}<0.001\right.$, Figure 1$)$. The roughly one to one slope is a strong indicator that H3A-4 is an accurate soil extractant for $\mathrm{P}$ when compared to H3A-3 (slope = 1.08). These data indicate that H3A-4 is extracting $\mathrm{P}$ within roughly $5 \%$ of $\mathrm{H} 3 \mathrm{~A}-3$.

Analysis of date from the rapid flow analyzer revealed that $\mathrm{H} 3 \mathrm{~A}-4$ extractable $\mathrm{PO}_{4}$ and H3A-3 extractable $\mathrm{PO}_{4}$ were very similar $\left(24.3 \mathrm{mg} \mathrm{PO} \mathrm{Pg}^{-1}\right.$ soil and $24.8 \mathrm{mg} \mathrm{PO}_{4} \mathrm{~kg}^{-1}$ soil, respectively). Extractable $\mathrm{PO}_{4}$ values were increased slightly when analyzed using the ICP (H3A-3, $36.3 \mathrm{mg} \mathrm{P} \mathrm{kg}^{-1}$ soil vs H3A-4, 36.6 mg P kg-1 soil). Extractable $\mathrm{PO}_{4}$ from the $\mathrm{H} 3 \mathrm{~A}-4$ and $\mathrm{H} 3 \mathrm{~A}-3$ extractants had a strong linear relationship $\left(\mathrm{r}^{2}=0.99, \mathrm{p}<0.001\right)$ when analyzed using the colorimetric method for $\mathrm{PO}_{4}-\mathrm{P}$ also (Figure 2). Note the slope is similar to that from Figure 1 (1.08 vs 1.05) indicating strong correlation between both machines (extractable $\mathrm{P}$ from ICP vs. extractable $\mathrm{PO}_{4}$ from RFA).

Extractable $\mathrm{NO}_{3}$-Nwas almost identical between the two extractants, which was expected since $\mathrm{NO}_{3}$-Nis considered water soluble $\left(r^{2}=0.99 \mathrm{p}<0.001\right.$, Figure 3). Figure 4 depicts the strong relationship between $\mathrm{NH}_{4}-\mathrm{N}$ extracted from 


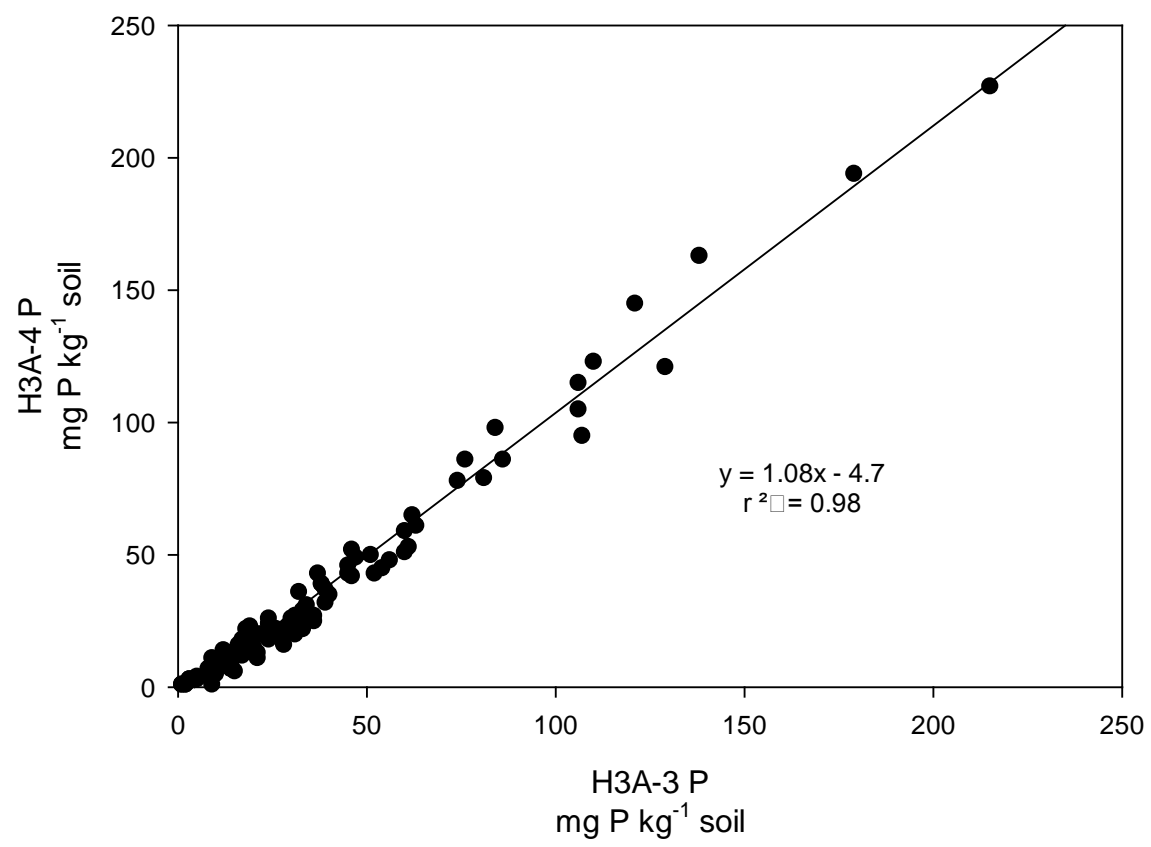

Figure 1. Linear relationship between P extracted with H3A-3 vs. H3A-4 from ICP analysis $\mathrm{P}<0.001$. The removal of licit rate slightly increased the amount of $\mathrm{P}$.

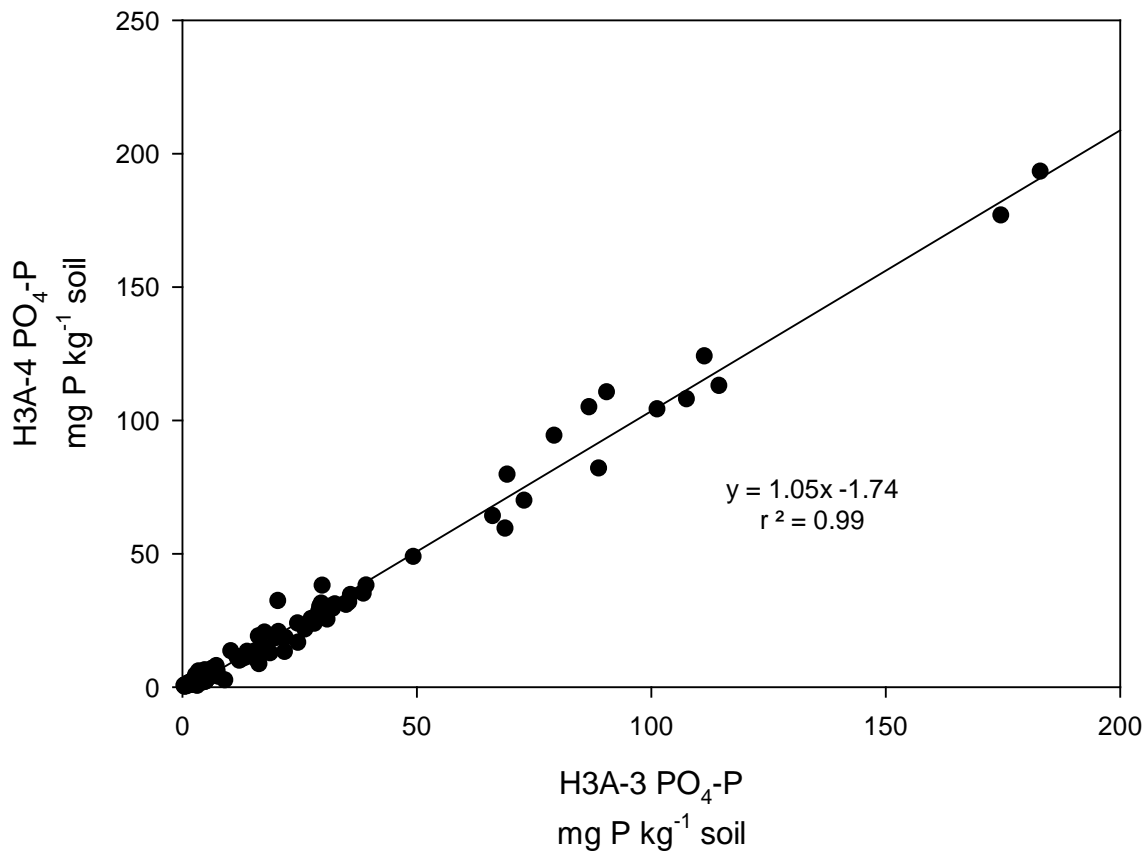

Figure 2. Linear relationship between $\mathrm{PO}_{4}$ extracted with $\mathrm{H} 3 \mathrm{~A}-3$ and $\mathrm{H} 3 \mathrm{~A}-4$ from colorimetric method $\mathrm{P}<0.001$. Note the slope is similar to that from Figure 1 (1.08 vs 1.05 ) indicating strong correlation between both machines (ICP vs. colorimetric).

H3A-3 and H3A-4 $\left(\mathrm{r}^{2}=0.99 \mathrm{p}<0.001\right)$. Figure 5 illustrates the same data with the highest $\mathrm{NH}_{4}-\mathrm{N}$ value removed, demonstrating that the correlation holds well at lower levels of extractable $\mathrm{NH}_{4}-\mathrm{N}\left(\mathrm{r}^{2}=0.99 \mathrm{p}<0.001\right)$. These data also indicate a slight increase in extractable $\mathrm{NH}_{4}-\mathrm{N}$ with $\mathrm{H} 3 \mathrm{~A}-4$ compared to H3A-3. 


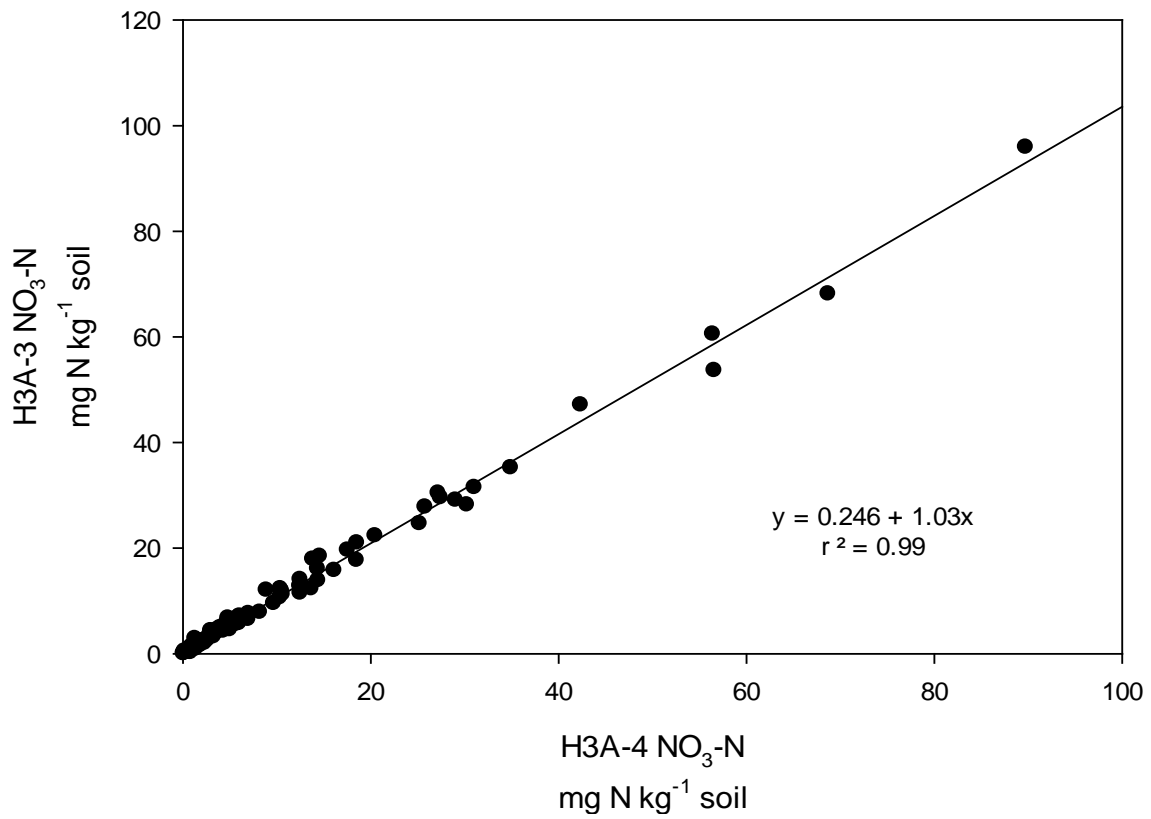

Figure 3. Linear relationship between $\mathrm{NO}_{3}$-Nextracted with $\mathrm{H} 3 \mathrm{~A}-4$ and $\mathrm{H} 3 \mathrm{~A}-3 \mathrm{P}<0.001$.

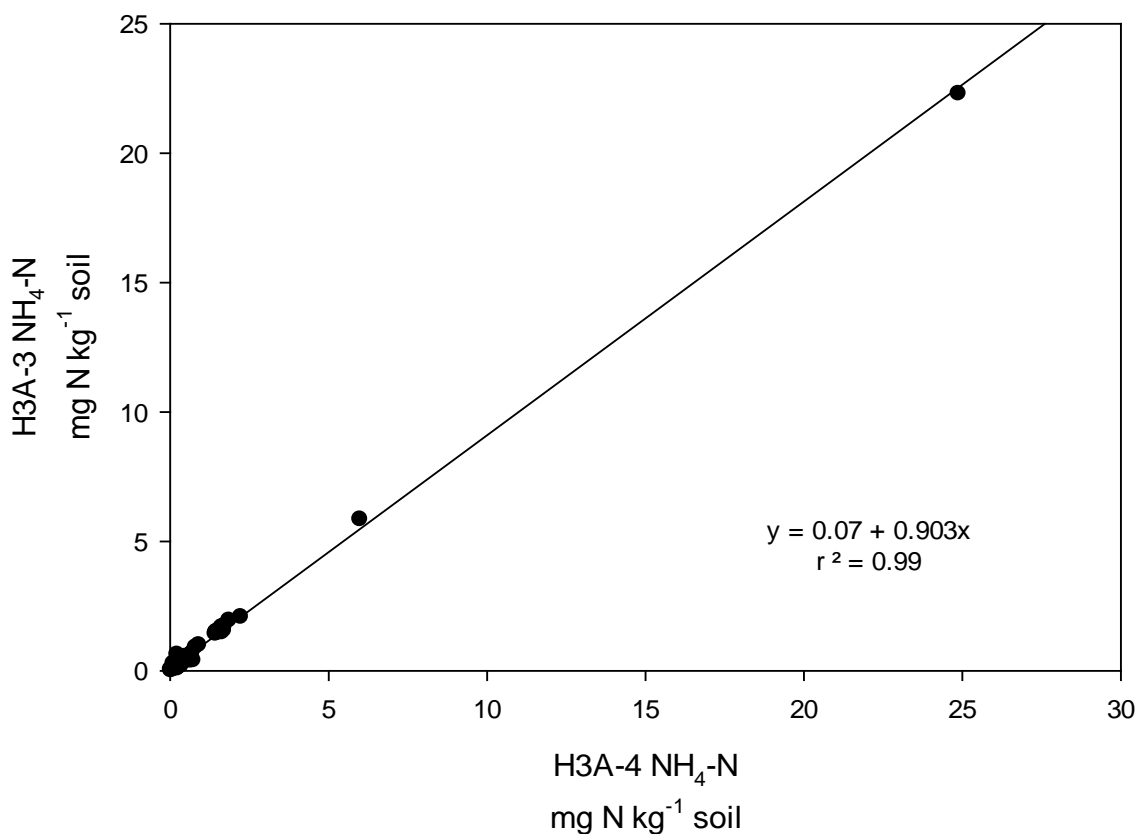

Figure 4. Linear relationship between $\mathrm{NH}_{4}-\mathrm{N}$ extracted with $\mathrm{H} 3 \mathrm{~A}-4$ and $\mathrm{H} 3 \mathrm{~A}-3 \mathrm{P}<0.001$.

Two samples had distinctly increased $\mathrm{Al}$ values when extracted with $\mathrm{H} 3 \mathrm{~A}-3$ compared to $\mathrm{H} 3 \mathrm{~A}-4$. H3A-4 greatly reduced the extractable $\mathrm{Al}$ of the two samples from $1420 \mathrm{mg} \mathrm{Al} \mathrm{kg}^{-1}$ soil to $160 \mathrm{mg} \mathrm{Al} \mathrm{kg}^{-1}$ soil (point 6a, Figure 6) and from $1300 \mathrm{mg} \mathrm{Al} \mathrm{kg}{ }^{-1}$ soil down to $200 \mathrm{mg} \mathrm{Al} \mathrm{kg}^{-1}$ soil (point 6b, Figure 6). With the outlier samples removed, regression analysis indicates that H3A-3 is displacing twice the amount $\mathrm{Al}$ compared to $\mathrm{H} 3 \mathrm{~A}-4(\mathrm{y}=1.8 \mathrm{x}-9.5)$. The correlation between $\mathrm{H} 3 \mathrm{~A}-3$ and $\mathrm{H} 3 \mathrm{~A}-4$ extractable $\mathrm{Al}$ was improved from $\mathrm{r}^{2}=0.42$ to $\mathrm{r}^{2}$ $=0.80$ with the two extreme samples removed. The relationship between H3A-3 


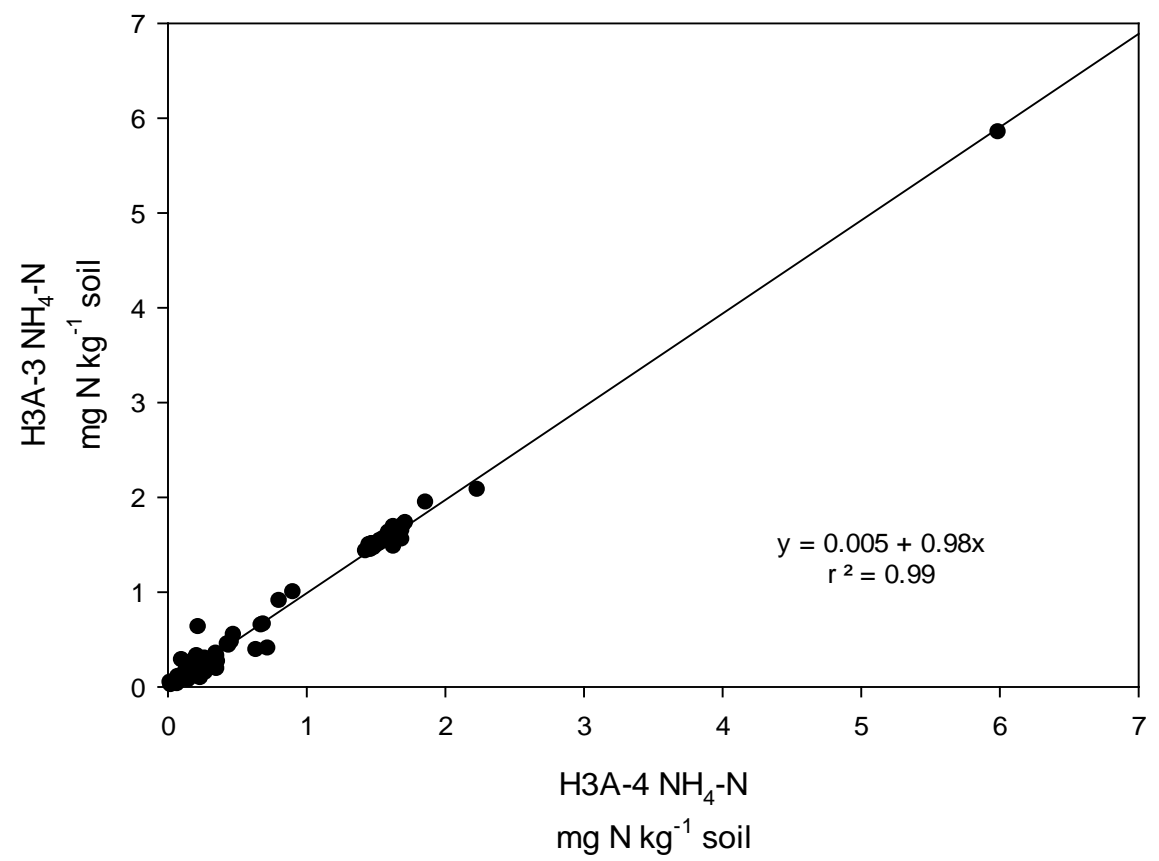

Figure 5. Linear relationship between ammonium extracted with H3A-3 and H3A-4P < 0.001 with the high sample removed from Figure 4 . This figure demonstrates that the correlation holds even with the high sample eliminated from the relationship.

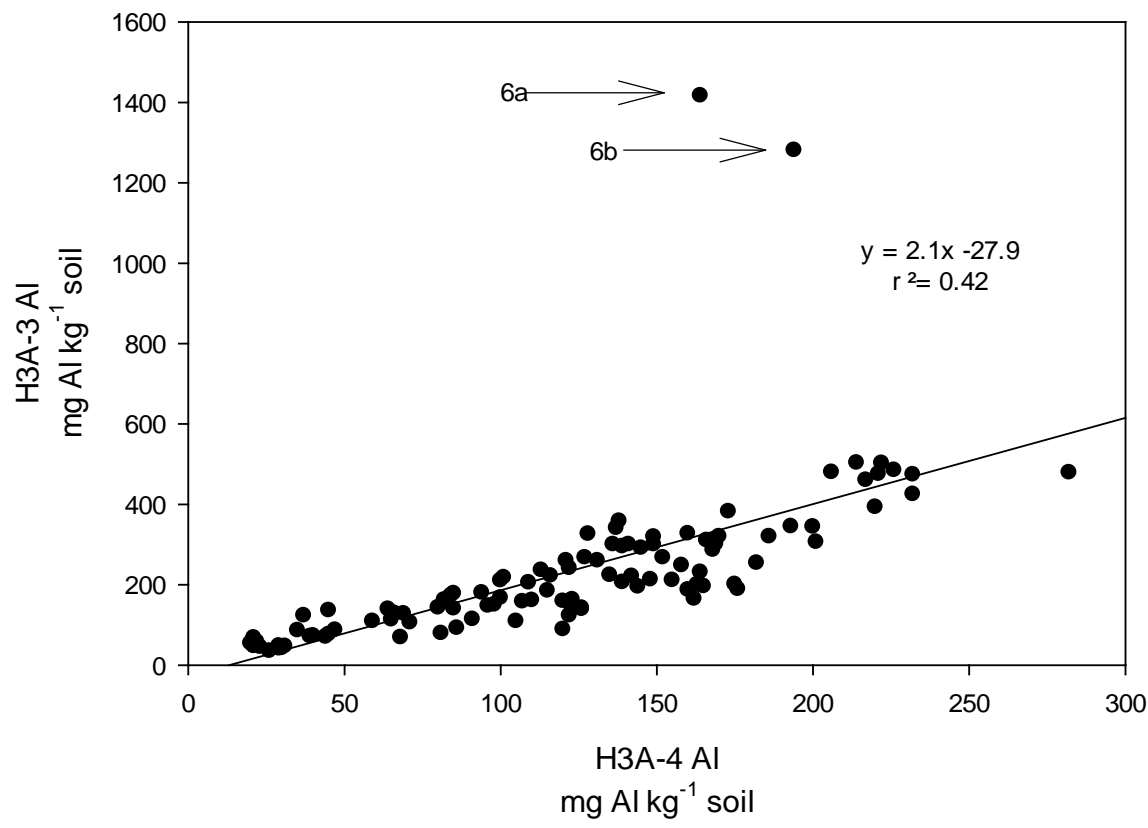

Figure 6. Linear relationship between $\mathrm{Al}$ extracted with $\mathrm{H} 3 \mathrm{~A}-3$ vs. H3A-4 from ICP analysis $\mathrm{P}<0.001$. The arrows point to the 2 samples that cleared after the removal of lithium citrate (Figure 8).

and H3A-4 extractable Fe was very similar to extractable $\mathrm{Al}\left(\mathrm{r}^{2}=0.45 \mathrm{p}<0.001\right.$, Figure 7). When the two highest Fe values were removed from the sample set, regression analysis indicates that $\mathrm{H} 3 \mathrm{~A}-4$ extracts roughly half of the Fe compared to H3A-3 $\left(y=15+1.8 x, r^{2}=0.81\right)$. Extractable Fe from the two samples 


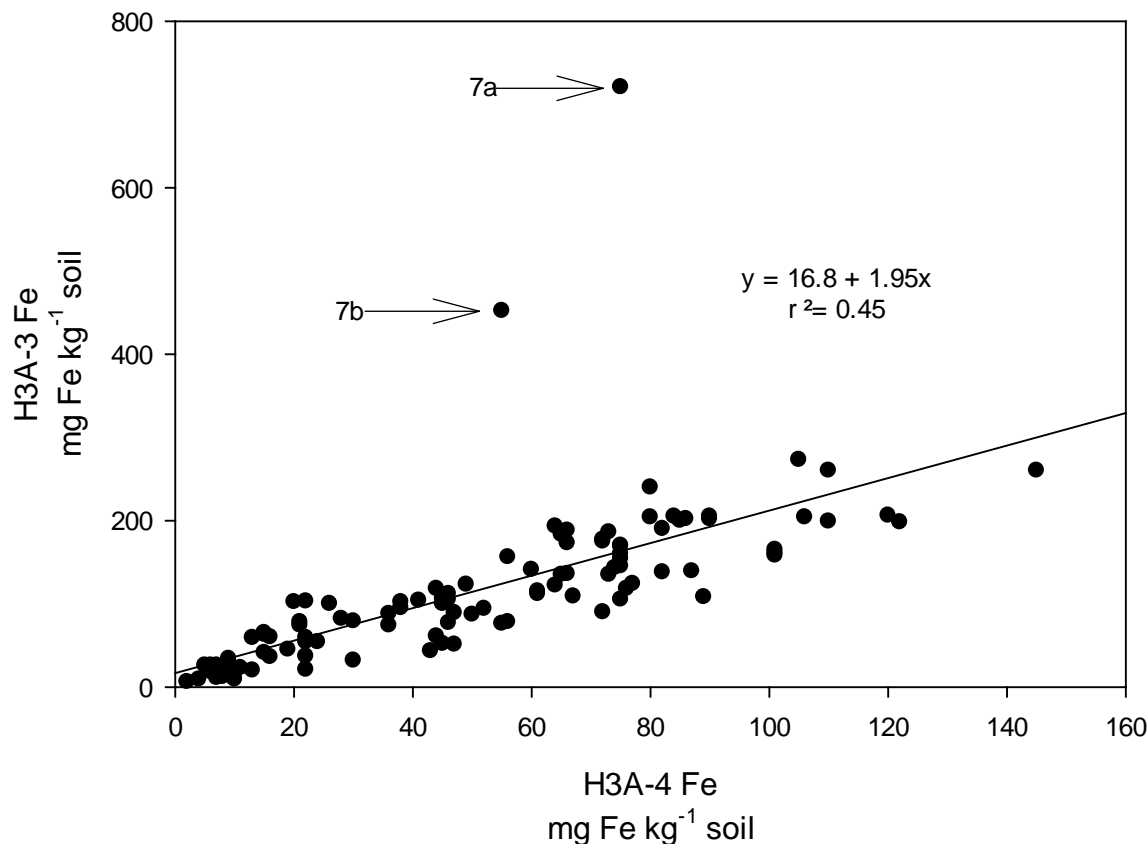

Figure 7. Linear relationship between Fe extracted with H3A-4 vs. H3A-3 from ICP analysis $\mathrm{P}<0.001$. The arrows point to the 2 samples that cleared as a result of the removal of lithium citrate (Figure 8).

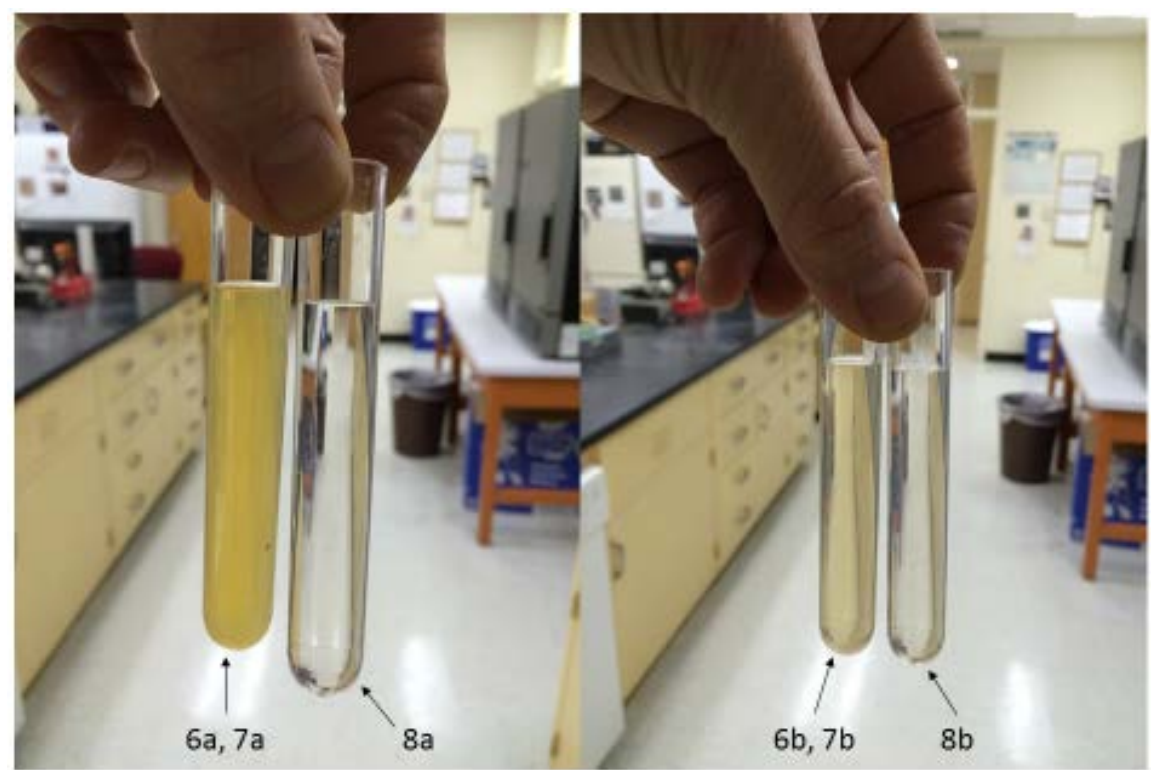

Figure 8. The visual difference between 2 of the soil extracts with lithium citrate and without lithium citrate (left side is soil 1, right side is soil 2), 6a and6bcorrespond with outliers for extractable Al, from Figure 6. Figure 7(a) and Figure 7(b) correspond with outliers for extractable Fe from (Figure 7). The supernatant from H3A-4 (8a and 8b) was much clearer resulting in lower aluminum and iron results.

decreased from $722 \mathrm{mg} \mathrm{Fe} \mathrm{kg}^{-1}$ soil to $78 \mathrm{mg} \mathrm{Fe} \mathrm{kg}^{-1}$ (point 7a, Figure 7) soil and from $480 \mathrm{mg} \mathrm{Fe} \mathrm{kg}^{-1}$ soil to $55 \mathrm{mg} \mathrm{Fe} \mathrm{kg}^{-1}$ soil (point 7b, Figure 7).

Removing Li-citrate from the extractant when applied to the two highly wea- 
thered, low $\mathrm{pH}$, soils (vials 6a, b and 7a, b; Figure 8) cleared the supernatant considerably (vials $8 \mathrm{a}$ and $8 \mathrm{~b}$, Figure 8). The two soils with higher $\mathrm{H} 3 \mathrm{~A}-3 \mathrm{Al}$ and $\mathrm{Fe}$ had low $\mathrm{pH}$ values, indicative of highly weathered soils. We speculate that the $\mathrm{Li}$ in Li citrate keeps $\mathrm{Fe}$ and $\mathrm{Al}$ in suspension due to its small size and ability to displace larger atoms, artificially inflating $\mathrm{Al}$ values. Exceptional values such as these are part of the reason Li citrate was ultimately removed from the H3A-3. From the thousands of samples we have analyzed over the years in the lab, we can predict, with relative accuracy, the extractable $\mathrm{Al}$ and $\mathrm{Fe}$ extracted from the soil based on color and cloudiness of the supernatant. Supernatant from soils with higher values of $\mathrm{Al}$ and $\mathrm{Fe}$ normally appear visually similar to the images in Figure 8.

Potassium was mostly unaffected by the removal of Li citrate except for one outlier shown in Figure 9, which is one of the samples that cleared because of the removal of $\mathrm{Li}$ citrate as seen in the picture from Figure 8. Regression analysis shows that the relationship between H3A-3 and H3A-4 extractable $\mathrm{K}$ can be described as $y=8.2+0.97 x\left(r^{2}=0.97 \mathrm{p}<0.001\right)$ with the outlier removed. The removal of Li citrate had negligible effect on extractable $\mathrm{Ca}$ (Figure 10). The slope of the regression line H3A-4 vs. H3A-3 was nearly 1:1 with a slight decrease in extractable Ca without Li citrate.

The most notable difference between H3A-3 and H3A-4 was the increase in percent $\mathrm{P}$ saturation $(\% \mathrm{P}$ sat $=($ extractable $\mathrm{P} /(\mathrm{Al}+\mathrm{Fe})) * 100)$ with $\mathrm{H} 3 \mathrm{~A}-4$ (Figure 11). The rise in \% $\mathrm{P}$ sat is due to the approximately two-fold decrease in $\mathrm{Al}$ and $\mathrm{Fe}$ extracted with $\mathrm{H} 3 \mathrm{~A}-4$ and relatively no change to extractable $\mathrm{P}$. Phosphorus saturation percentages over 15 commonly indicate that $\mathrm{P}$ fertilizer has been applied or excessive P is available. Averaged across all samples, \%P sat

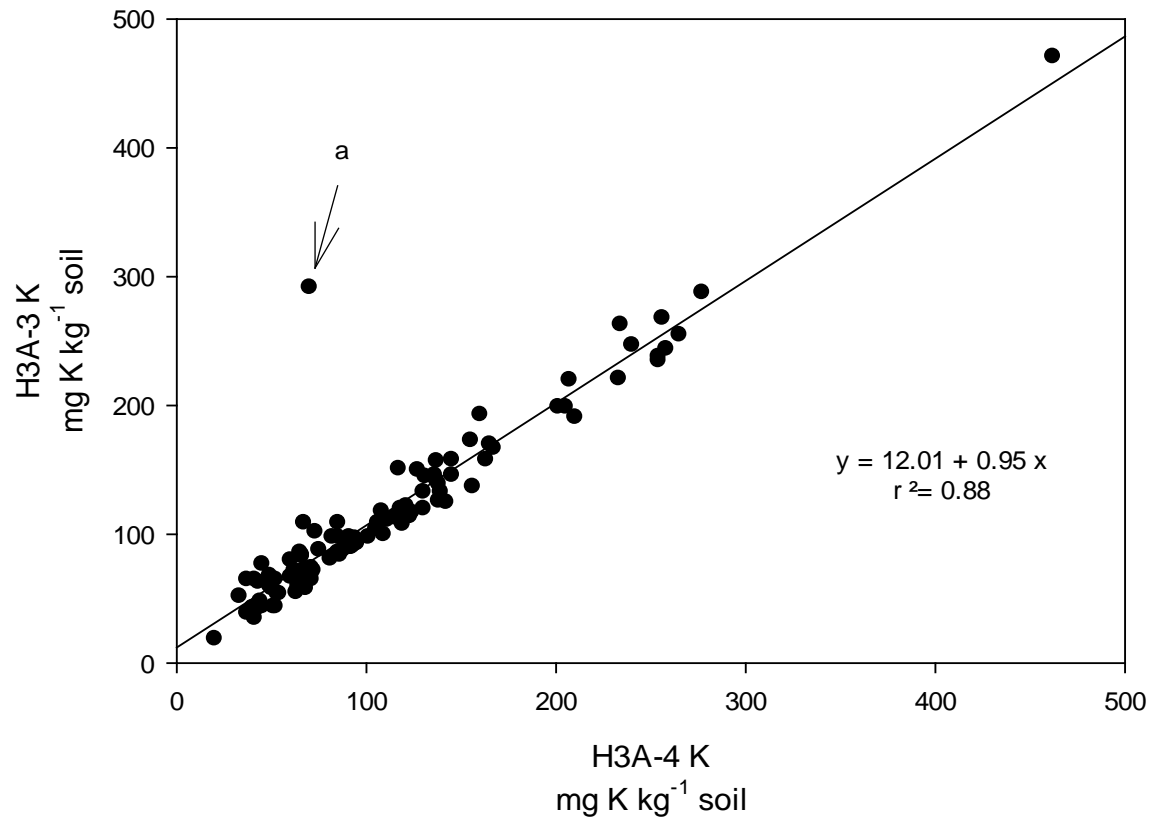

Figure 9. Linear relationship between $\mathrm{K}$ extracted with H3A-4 vs. H3A-3 from ICP analysis $\mathrm{P}<0.001$. The outlier (a) is from Figure 8 and is tube 6 a from soil 1 . 


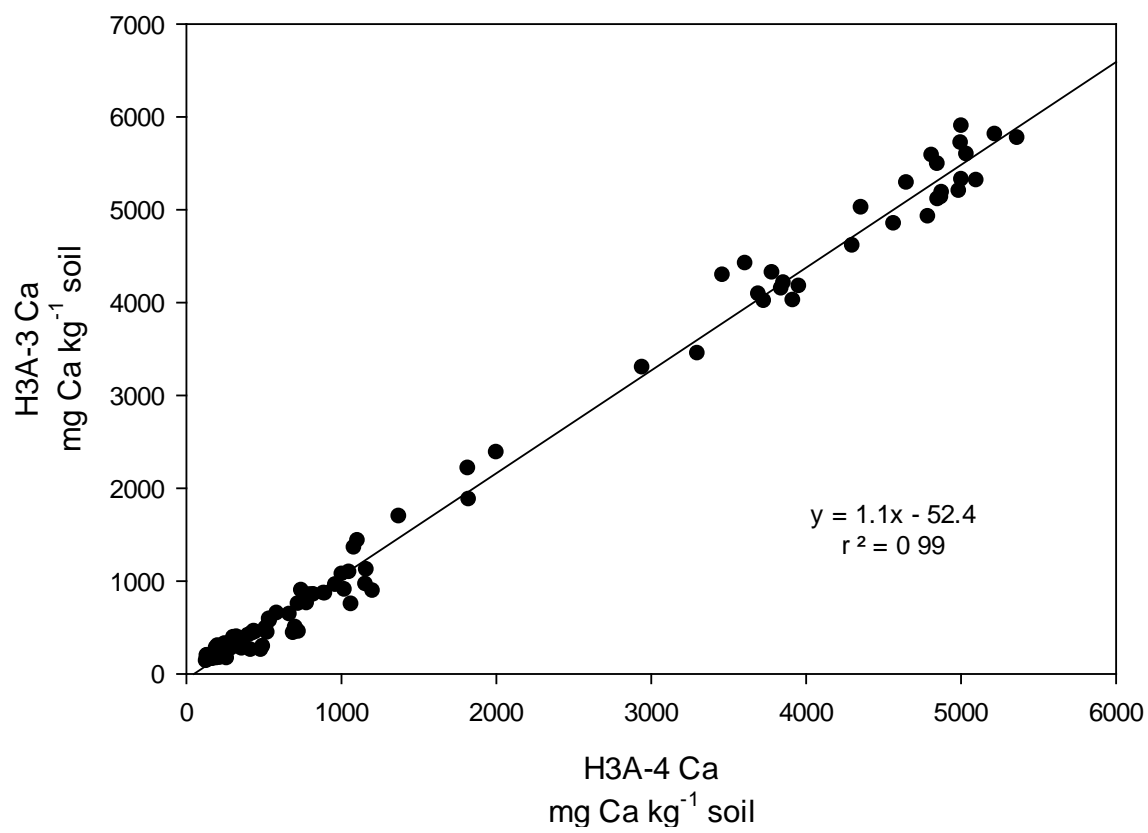

Figure 10. Linear relationship between $\mathrm{Ca}$ extracted with $\mathrm{H} 3 \mathrm{~A}-4$ vs. H3A-3 from ICP analysis $\mathrm{P}<0.001$. The removal of Li citrate had very little effect upon extractable $\mathrm{Ca}$.

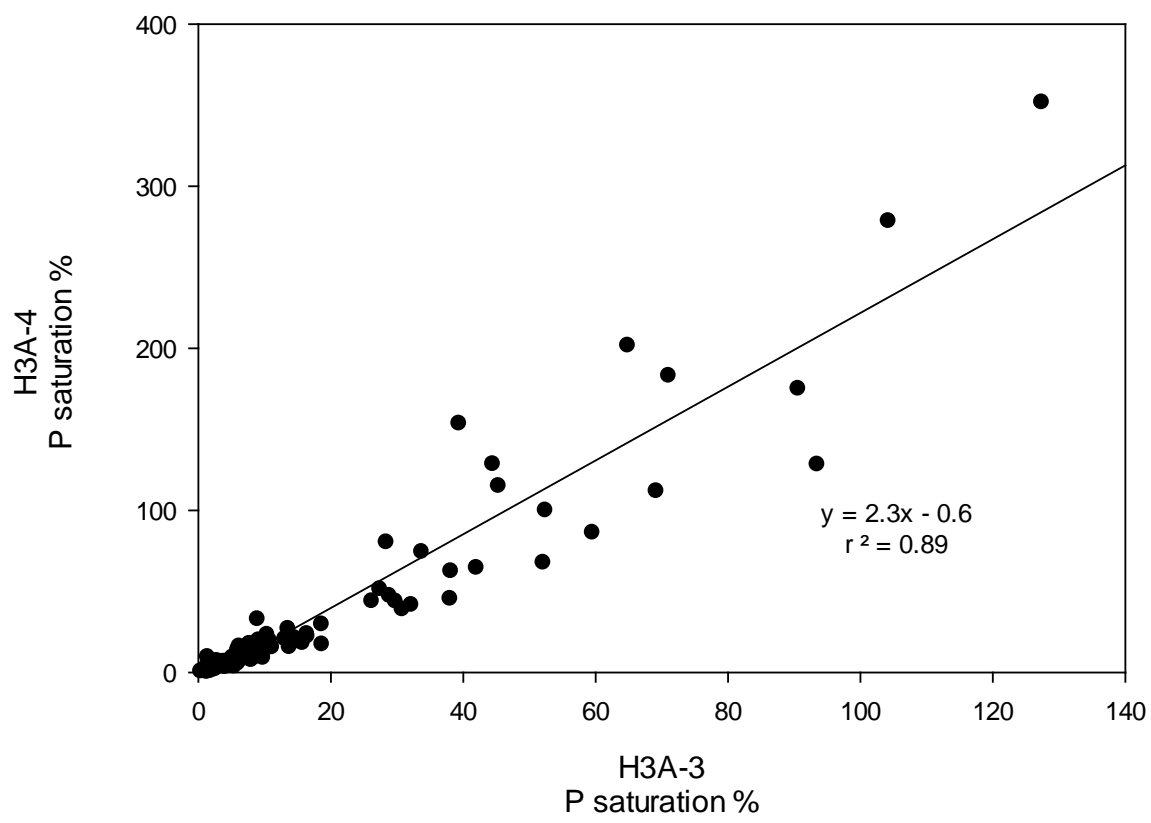

Figure 11. Percent phosphate saturation from $\mathrm{H} 3 \mathrm{~A}-3$ vs. $\mathrm{H} 3 \mathrm{~A}-4 \mathrm{P}<0.001$.

is 17.3 for $\mathrm{H} 3 \mathrm{~A}-3$ and 33.5 for $\mathrm{H} 3 \mathrm{~A}-4$, thereby doubling the scale withH3A-4. Therefore, the new ratio would indicate adequate $\mathrm{P}$ at $30 \% \mathrm{P}$ sat and excessive $\mathrm{P}$ above $30 \%$. Percent $\mathrm{P}$ saturation is an excellent indicator of excessive $\mathrm{P}$ when we receive samples from fields to which no $\mathrm{P}$ fertilizer has been recently applied.

Phosphate recommendations are known to be inherently unreliable over a wide range of soils [24] [25] [26]; therefore our approach to soil testing differs from traditional soil tests for plant available P. Laboratories using Bray, Mehlich 
and Olsen find a critical value for extractable $\mathrm{P}$ and rate soils as having a low, medium or high $\mathrm{P}$ response probability. $\mathrm{P}$ recommendations are therefore based on $\mathrm{P}$ response curves to added $\mathrm{P}$ fertilizer from field trials of a few sample soils. This approach does not account for the plants ability to naturally extract $\mathrm{P}$ through root exudates under varying climatic conditions as well as variations in management such as no-till versus conventional-till. Additionally, fertilizer response curves are known to be highly variable year to year [27], decreasing the likelihood that $\mathrm{P}$ recommendations will be on target with crop needs. The best soil tests are those that are insensitive to soil type [28] and thereby viable over a wide range of soils. Menon [29] stated at the time, only the water and anion exchange resin methods can be considered insensitive to the soil types.

Fertilizer recommendations from soil-testing with H3A-4 are dynamic because we account for the inherent soil chemistry and natural plant biochemistry, as has been shown by Somenahally [8] and Haney [11]. Somenahally [8] indicate that $\mathrm{H} 3 \mathrm{~A}$ is much improved over Mehlich 3 for plant-available nutrient determination because $\mathrm{H} 3 \mathrm{~A}$ mimics the soil-root microenvironment and preserves ambient soil $\mathrm{pH}$ levels. The amount of $\mathrm{P}$ extracted is subtracted from the $\mathrm{P}$ needed for the given crop based on yield goal. This innovative approach is more versatile because it assesses the soil in its natural state as opposed to an artificially induced chemical state. The artificial extraction environment was based on the lack of understanding of the complex and dynamic living soil system. For example, if Mehlich extracts $50 \mathrm{mg} \mathrm{P} \mathrm{kg}{ }^{-1}$ soil, a fertilizer response curve indicates that no fertilizer $\mathrm{P}$ is needed. On the same soil, when $\mathrm{H} 3 \mathrm{~A}$ extracts $21 \mathrm{mg} \mathrm{P}$ $\mathrm{kg}^{-1}$ soil, we convert the value to $\mathrm{P}_{2} \mathrm{O}_{5}$ resulting in $58 \mathrm{~kg} \cdot h a^{-1}$ of available $\mathrm{P}_{2} \mathrm{O}_{5}$. If the yield goal is $12.56 \mathrm{Mg} / \mathrm{ha}$ corn, which requires $84 \mathrm{~kg} \mathrm{P}_{2} \mathrm{O}_{5} \mathrm{ha}^{-1}$, then we recommend applying $26 \mathrm{~kg} \mathrm{P}_{2} \mathrm{O}_{5} \mathrm{ha}^{-1}$. Mehlich 3 recommendations may have resulted in under application of $\mathrm{P}$. While critical values are an understandable and broad approach, all soils within a region are treated the same regardless of inherent soil properties. The only flexibility in Mehlich recommendations comes from different regions of the US. Lobell [30] found that within-field soil variability is greater than variability in weather when water availability is not a limiting factor so we must attempt to account for variations in soil in our fertilizer recommendations versus regional blanket approaches.

\section{Conclusions}

H3A-4 was developed to overcome the inherent over- or under-estimations of plant available nutrients when soil extractants are too harsh (i.e. very high or low $\mathrm{pH}$ ) or too weak (water). Fertilizer recommendations based on response curves are outdated and ignore the inherently variable soil and climatic factors. While it is not ideal to forgo field studies for every nutrient extractant, there is a shortage of time, funding, and labor to conduct the far-reaching research that would be needed to test over the vast gamut of soils and climatic conditions. Coupled with the fact that farmers need updated nutrient management information now, and 
not in another 20 to 40 years, it is critically important to advance our soil-testing techniques so we can give producers the best data available without extensive multi-year greenhouse or research plot experiments. A move toward on-farm research could promote advances in soil analyses, ultimately benefiting producers as they endeavor to yield high quality feed and fiber efficiently and economically.

We found it remarkable that extractable $\mathrm{P}$ values can be altered so easily by using a natural process as the foundation of development. The variations in the H3A extractant over time have been somewhat subtle, yet have effectively improved extractable $\mathrm{P}$ capitalizing on a biomimicry approach. The first iteration (H3A-1) was a little more aggressive in extracting $P$ than was H3A-2. Transition to $\mathrm{H} 3 \mathrm{~A}-3$ resulted in a very strong relationship with FeAlO extractable $\mathrm{P}$ (Haney et al., 2016). The modifications to H3A-3, although slight, have cleared the supernatant and appear to have eliminated excess $\mathrm{Al}$ and $\mathrm{Fe}$ from highly weathered low $\mathrm{pH}$ soils. The relationships between $\mathrm{H} 3 \mathrm{~A}-3$ extractable $\mathrm{P}, \mathrm{K}$ and $\mathrm{Ca}$ and H3A-4 are only slightly changed and therefore appear to maintain the relationship previously found with FeAlO extractable (Haney et al. 2016). The H3A-4 soil extractant demonstrates that our endeavor to mimic the natural processes in the lab were successful. The results will undoubtedly improve our P fertilizer recommendations for producers.

\section{References}

[1] Sholford, I.C.R. (1980) Greenhouse Evaluation of Four Phosphorus Soil Tests in Relation to Phosphate Buffering and Labile Phosphate in Soil. Soil Science Society of America Journal, 44, 555-559. https://doi.org/10.2136/sssaj1980.03615995004400030024x

[2] Golterman, H.L. (1998) Relections on Fractionation and Bioavailability of Sediment Bound Phosphate. Archiv für Hydrobiologie, 30, 1-4.

[3] Sharpley, A.N. (1993) An Innovative Approach to Estimate Bioavailable Phosphorus in Agricultural Runoff by Fe Oxide-Impregnated Paper. Journal of Environmental Quality, 22, 597-601. https://doi.org/10.2134/jeq1993.00472425002200030026x

[4] Nelson, W.L., Mehlich, A. and Winters, E. (1953) The Development, Evaluation, and Use of Soil Tests for Phosphorus Availability. In: Pierre, W.H. and Norman, A.G., Eds., Soil and Fertilizer Phosphorus in Crop Nutrition. Academic Press Inc, New York, 153-188.

[5] Mehlich, A. (1984) Mehlich 3 Soil Test Extractant. A Modification of the Mehlich 2 extractant. Communications in Soil Science and Plant Analysis, 15, 1409-1416. https://doi.org/10.1080/00103628409367568

[6] Olsen, S.R., Cole, C.V., Watanabe, F.S. and Dean, L.A. (1954) Estimation of Available Phosphorus in Soils by Extraction with Sodium Bicarbonate. USDA Circ. 939. U.S. Government Printing Office, Washington DC.

[7] Sharpley, A.N. (1991) Soil Phosphorus Extracted by Iron-Aluminum-Oxide Impregnated Filter Paper. Soil Science Society of America Journal, 55, 1038-1041. https://doi.org/10.2136/sssaj1991.03615995005500040025x

[8] Havlin, J.L., Tisdale, S.L., Beaton, J.D. and Nelson, W.L. (2005) Soil Fertility and 
Fertilizers: An Introduction to Nutrient Management. Prentice Hall, Upper Saddle River.

[9] Somenahally, A.D.C., Weindorf, L., Darilek, J.P., Muir, R., Wittie, C., Thompson and Morgan, C.L.S. (2009) Spatial Variability of Soil Test Phosphorus in Manure-Amended Soils on Three Dairy Farms in North Central Texas. Journal of Soil and Water Conservation, 64, 89-97. https://doi.org/10.2489/jswc.64.2.89

[10] Ketterings, Q.M., Czymmek, K.J., Reid, W.S. and Wildman, R.F. (2002) Conversion of Modified Morgan and Mehlich-3 Soil Tests to Modified Morgan Soil Test Values. Soil Science, 167, 830-837. https://doi.org/10.1097/00010694-200212000-00007

[11] Haney, R.L., Haney, E.B., Hossner, L.R. and Arnold, J.G. (2006) A New Soil Extractant for Simultaneous Phosphorus, Ammonium, and Nitrate Analysis. Communications in Soil Science and Plant Analysis, 37, 1511-1523. https://doi.org/10.1080/00103620600709977

[12] Haney, R.L., Haney, E.B., Hossner, L.R. and Arnold, J.G. (2010) Modifications to the New Soil Extractant H3A-1: A Multinutrient Extractant. Communications in Soil Science and Plant Analysis, 41, 1513-1523. https://doi.org/10.1080/00103624.2010.482173

[13] Rengel, Z. (1997) Root Exudation and Microflora Populations in Rhizosphere of Crop Genotypes Differing in Tolerance to Micronutrient Deficiency. Plant Soil, 196, 255-260. https://doi.org/10.1023/A:1004262326715

[14] Baudoin, E., Benizri, E. and Guckert, A. (2003) Impact of Artificial Root Exudates on the Bacterial Community Structure in Bulk Soil and Maize Rhizosphere. Soil Biology and Biochemistry, 35, 1183-1192.

[15] Hinsinger, P. (2001) Bioavailability of Soil Inorganic P as Affected by Root-Induced Chemical Changes-A Review. Plant Soil, 237, 173-178. https://doi.org/10.1023/A:1013351617532

[16] Azaizeh, H.A., Marschner, H., Romheld, V. and Wittenmayer, L. (1995) Effects of Vesicular-Arbuscular Mycorrhizal Fungus and Other Soil Microorganisms on Growth, Mineral Nutrient Acquisition and Root Exudation of Soil-Grown Maize Plants. Mycorrhiza, 5, 5321-5327. https://doi.org/10.1007/BF00207404

[17] Subbarao, G.V., Ae, N. and Otani, T. (1997) Genotypic Variation in Iron and Aluminum-Phosphate Solubilizing Activity of Pigeonpea Root Exudates under P Deficient Conditions. Soil Science and Plant Nutrition, 43, 295-305. https://doi.org/10.1080/00380768.1997.10414754

[18] Ryan, P.R., Skerrett, M., Findlay, G.P., Delhaize, E. and Tyreman, S.D. (1997) Aluminum Activates and Anion Channel in the Apical Cells of Wheat Roots. Proceedings of the National Academy of Sciences, 94, 6547-6552. https://doi.org/10.1073/pnas.94.12.6547

[19] Zheng, S.J. and Ma, J.F. (1998) Continuous Secretion of Organic Acids Is Related to Aluminum Resistance during Relatively Long-Term Exposure to Aluminum Stress. Physiology Plant, 103, 209-214. https://doi.org/10.1034/j.1399-3054.1998.1030208.x

[20] Mehta, S., Sharma, S. and Sindhan, G.S. (1992) Analysis of Root Exudates of Cowpea and Their Influence on the Growth of Rhizoctoniasolani. Indian Journal of Mycology and Plant Pathology, 22, 227-231.

[21] Gerke, J. (1992) Phosphate, Aluminum, and Iron in the Soil Solution of Three Different Soils in Relation to Varying Concentrations of Citric Acid. Zeitschrift für Pflanzenernährung und Bodenkunde, 155, 339-346. https://doi.org/10.1002/jpln.19921550417

[22] Haney, R., Haney, E., Harmel, R., Smith, D. and White, M. (2016) Evaluation of 
H3A for Determination of Plant Available P vs. FeAlO Strips. Open Journal of Soil Science, 6, 175-187. https://doi.org/10.4236/ojss.2016.611017

[23] Oburger, E., Kirk, G.J.D., Wenzel, W.W., Puschenreiter, M. and Jones, D.L. (2009) Interactive Effects of Organic Acids in the Rhizosphere. Soil Biology and Biochemistry, 41, 449-457.

[24] Cox, F.R. (1994) Current Phosphorus Availability Indices: Characteristics and Shortcomings. Soil Testing: Prospects for Improving Nutrient Recommendations: Soil Science Society of America Special Publication. Journal of Agricultural Science, 40, 101-113.

[25] Jordan-Meille, L., Rubaek, G.H., Ehlert, P.A.I., Genot, V., Hofman, G., Goulding, K. and Barrachlough, P. (2012) An Overview of Fertilizer-P Recommendations in Europe: Soil Testing, Calibration and Fertilizer Recommendations. Soil Use and Management, 28, 419-435. https://doi.org/10.1111/j.1475-2743.2012.00453.x

[26] Sharpley, A.N. (1994) Innovative Soil Phosphorus Availability Indices: Assessing Inorganic Phosphorus. Soil Testing: Prospects for Improving Nutrient Recommendations. Soil Science Society of America Special Publication, 40, 115-142.

[27] Haney, E.B., Haney, R.L., White, M.J., Arnold, J.G., Raun, W.R. and Fay, P.A. (2017) In Review. SWAT and SWAT-Flush Simulated vs. Actual Yield in Long-Term Trials. Journal of the American Water Resources Association.

[28] Menon, R.G., Hammond, L.L. and Sissingh, H.A. (1989) Determination of Plant-Available Phosphorus by the Iron Hydroxide-Impregnated Filter Paper $\left(\mathrm{P}_{\mathrm{i}}\right)$ Soil Test. Soil Science Society of America Journal, 52, 110-115. https://doi.org/10.2136/sssaj1989.03615995005300010020x

[29] Menon, R.G., Chien, S.H. and Hammond, L.L. (1988) Comparison of Bray I and Pi Tests for Evaluating Plant-Available Phosphorus from Soils Treated with Different Partially Acidulated Phosphate Rocks. Plant Soil, 114, 211-216. https://doi.org/10.1007/BF02220800

[30] Lobell, D.B., Ortiz-Monasterio, J.I. and Anser, G.P. (2004) Relative Importance of Soil and Climate Variability for Nitrogen Management in Irrigated Wheat. Field Crops Research, 87, 155-165. 